\title{
Presentación \\ EN DIÁLOGO CON LAS LITERATURAS DE AMÉRICA LATINA: A CIEN AÑOS DE LA MUERTE DE ALBERTO BLEST GANA
}

Nos complace inaugurar un nuevo espacio en la Revista Chilena de Literatura. Esta sección está animada por el propósito de ofrecer reflexiones con razón de efemérides, conmemoraciones y otros momentos significativos de la historia literaria latinoamericana y chilena en particular. Este volver el rostro al tiempo denso de lo acontecido supone una mirada indagatoria y abierta al diálogo, en un gesto que se justifica por la relevancia crítica de la materia abordada en relación con el tiempo presente. Las figuras, problemas y textos que aparezcan en estas páginas son entendidos entonces como vigentes, como puentes entre la historia y la contingencia crítica. En ese sentido, los estudios que tendrán cabida en esta sección supondrán un posicionamiento sobre un problema contemporáneo relevado por un diálogo con el pasado, que por esta misma razón no puede planificarse con la misma antelación que las contribuciones habituales a la revista. La sección no será regular, sino que responderá a la necesidad del debate académico en las fechas significativas del calendario literario latinoamericano.

La primera sección especial está dedicada a la obra del principal novelista del siglo XIX chileno y al fundador de la tradición realista en el país, Alberto Blest Gana (Santiago, 4 de mayo de 1830-París, 9 de noviembre de 1920). Para conmemorar los cien años de su muerte presentamos cuatro artículos que dan cuenta del amplio y diverso interés que suscita su obra actualmente en la crítica literaria. La serie echa luz sobre dimensiones o corpus poco estudiados de la obra de Blest Gana o bien profundiza y afina posiciones que se inscriben en debates de larga data.

Abre Ignacio Álvarez, quien observa el cambio de sentido que sufrieron en Los trasplantados (1904) las estrategias narrativas ya presentes en Martín Rivas (1862): el regreso del realismo a la metrópolis francesa convierte la celebración del burgués en la humillación del rastacuero. Luego, Laura 
Hosiasson llama la atención sobre el vasto e ignorado material de la primera etapa productiva de Blest Gana, para develar un individualismo romántico a partir del cual se pueden pensar transformaciones y permanencias en la trayectoria del novelista. En tercer lugar, Carla Rojas lee la producción tardía de Blest Gana y descubre una complejización de sus imaginarios geopolíticos, proceso ligado a un cambio en la conciencia del autor sobre las escalas de impacto de su literatura al despuntar el siglo XX. Por último, Grínor Rojo revisita Martín Rivas recontextualizándolo respecto del tiempo histórico de la representación y en contraste con el fondo textual europeo, en un movimiento que precisa la problemática social del clásico y renueva la originalidad en la periferia del capitalismo.

Equipo Editorial

Horst Nitschack, Director Alejandra Ortiz Salamovich, Secretaria de Redacción Pablo Concha Ferreccio, Asistente Editorial 